Publisher: Faculty of Agronomy Čačak

\title{
Priming seeds-method for increasing the germination of soybean seeds under drought stress conditions
}

\author{
Zlatica Miladinov*1, Ivana Maksimović2 ${ }^{2}$ Svetlana Balešević Tubić ${ }^{1}$, Vojin Đukić ${ }^{1}$, \\ Zorica Nikolić ${ }^{1}$, Branko Milošević ${ }^{1}$, Snežana Katanski ${ }^{1}$ \\ 1 Institute of Field and Vegetable Crops, Maksima Gorkog 30, 21000 Novi Sad, Serbia \\ 2Faculty of Agronomy, University of Novi Sad, Dositeja Obradovića 8, 21000 Novi Sad, Serbia
}

*Corresponding author: zlatica.miladinov@ifvcns.ns.ac.rs

Received 18 May 2020; Accepted 22 July 2020

\begin{abstract}
A B S T R A C T
Drought is one of the most important factors limiting the successful production of cultivated plants. One of the most sensitive stage to the water deficit in plants is seed germination. There are various methods of pre-sowing treatments that aim to reduce the negative impact of drought stress and improve seed germination. One of them is priming seeds. The aim of this experiment was to examine the effect of priming seeds in solutions - KNO3 (1\%), ascorbic acid - AsA (100 mgl-1) and potassium chloride KCl $(1 \%)$ on the reduction of the negative effect of drought stress. The effect of drought stress was simulated using different concentrations of PEG 6000 (0 (control), $-0.30,-0.51,-0.80 \mathrm{MPa}$ ). The results of the research showed that with the increase of water deficiency, the effect of priming seeds is greater. At the water potential of the solution of $-0.30 \mathrm{MPa}$, germination energy and seed germination increased on average by $6.77 \%$ and $5.08 \%$, while at the water potential of the solution of $-0.80 \mathrm{MPa}$, the increase was $19.28 \%$ and $16.75 \%$, respectively. Also, priming seeds significantly reduced the intensity of lipid peroxidation and the content of free proline.

From all the above, it can be concluded that priming of seeds is a method that can serve to improve the germination of soybean seeds in conditions of drought stress.
\end{abstract}

Keywords: drought stress, Glycine max., priming seed, seed germination.

\section{И 3 В $о$ д}

Суша је један од најважнијих фактора који ограничава успешну производњу културних биљака. Једна од најосетљивијих фаза на недостатак воде код биљака је клијање семена. Постоје разне методе односно предсетвени третмани кој имају циљ да смање негативан утицај недостатка воде и побољшају клијање семена. Један од њих је потапање семена. Циљ овог експеримента био је да се испита утицај потапања семена у растворе - KNO3 (1\%), аскорбинску киселину - AsA (100mgl-1) и калијум хлорид $\mathrm{KCl}(1 \%)$ на смањење негативног утицаја суше. Дејство суше симулирано је применом различитих концентрација PEG-a 6000 (0 (контрола), -0,30, -0,51, -0,80 MPa). Резултати истраживања су показали да је са повећањем недостатка воде ефекат потапања семена већи. При водном потенцијалу раствора од -0,30 МРа енерија клијања и клијавост семена повећани су, у просеку, за 6,77\% односно 5,08\% док је при водном потенцијалу раствора од 0,80 МРа повећање износило 19,28\% односно 16,75\%. Такође, потапање семена значајно је смањило интензитет липидне пероксиације и садржај слободног пролина.

Из свега наведеног може се закључити да је потапање семена метод који може да побољша клијање семена соје у условима суше.

Кључне речи: суша, Glycine тах., потапање семена, клијавост семена.

\section{Introduction}

Seed priming was an age-old technique practiced by the Greek farmers. Theophrastus (372-287 BC) primed cucumber seeds before sowing in milk or water to germinate earlier and have greater germination energy (Evenari, 1984). Pre-hydration of legume seeds before sowing was performed by Roman farmers in order to increase the germination rate and synchronize germination as reported by the Roman naturalist Gaius Plinius Secundus. Several centuries later, these techniques were still used for a wide range of species according to the French agronomist Olivier de Serres (1539-1619) (Evenari, 1984). The word seed priming was coined by Heydecker in 1973 and he successfully adopted seed priming to improved seed germination and emergence under stressful conditions (Sivasubramaniam et al., 2011). In the beginning of the XXI century, priming seed is a economic and simple pre-sowing treatment that is usually used in in countries in transition (Harris et al., 2001) that is, applied by farmers who cannot use other expensive and complex methods to stimulate germination (Ozdemir et al., 2012). Several methods of seed priming have been developed in order to invigorate seeds and alleviate the environmental stresses. A common feature of water-based priming techniques, which distinguishes them from other pre-sowing treatments, is partial seed pre-hydration and the activation of early 
germination events in seed. The benefits of priming seed on all crops are faster and greater germination and sprouting, greater vigor of the plant, earlier flowering, and thus earlier harvest and higher yield.

A major limitation in agricultural production worldwide is the deficit water during germination, leading to a reduction or even complete absence of germination (Kaya et al., 2006). In many countries in Asia and Africa, seed priming is the best method to mitigate the negative effects of drought stress in the germination and sprouting (Harris, 2001). Certain solutions can be used to induce drought under controlled conditions. One of them is polyethylene glycol - PEG (H(OCH2CH2)nOH). PEG is a long-chain, chemically inert polymer, used in water stress simulation experiments (Murillo-Amador et al., 2002). Back in 1961, PEG was introduced as a compound that can be used to alter the osmotic potential of a solution and cause a water deficit. PEG 6000 binds water, but due to the size of its molecules, it cannot be absorbed by the plant. Thus, it causes a state of physiological drought, that is, prevents the plant from accepting water (Alexieva et al., 2001). PEG has no toxic effect (Khajeh-Hosseini et al., 2003).

Therefore, the objective of this experiment was to compare the effect of drought stress on two soybean varieties and seed priming with potassium nitrate (KNO3), ascorbic acid (AsA) and potassium chloride (KCl), with the hypothesis that seed priming can mitigate the adverse effect of drought stress.

\section{Material and Methods}

Trial was set and carried out in the Institute of Field and Vegetable Crops Novi Sad. The tests included two soybean varieties, NS Zita and Victoria. Initial germination value of both varieties was $88 \%$, while moisture content was $10-11 \%$. Before priming, seeds were sterilized with $3 \%$ solution of sodium hypochlorite $(\mathrm{NaOCl})$ for two minutes and rinsed with distilled water. In order to determine the impact of seed priming on germination in the presence of PEG, seeds were primed into different solutions: potassium nitrate - KNO3 (1\%), ascorbic acid AsA - (100mgl-1) and potassium chloride - $\mathrm{KCl}(1 \%)$. The ratio among seed mass and solution volume was 1:5 (v/v). After $6 \mathrm{~h}$ (Miladinov et. al., 2015) seeds were washed out with a jet of distilled water and dried at $25^{\circ} \mathrm{C}$ up to moisture content of $10-11 \%$. The effect of drought was examined by germinating seeds at different concentrations of water-soluble PEG 6000. These are the concentrations that provide the osmotic potential of solution 0 (control), $-0.30,-0.51$, and $-0.80 \mathrm{MPa}$, respectively. Seeds were distributed on a sterilized filter paper, in Petri dishes $9 \mathrm{~cm}$ in diameter. Then, 4 x 50 seeds were treated with $10 \mathrm{ml}$ of distilled water and set as a randomized block design. Petri pots were closed using paraffin tape in order to prevent moisture loss and avoid contamination. Petri pots were placed in chambers to germinate at $25{ }^{\circ} \mathrm{C}$ and $95 \%$ relative humidity for 8 days. Results ere collected daily and seed germination was defined by protrusion of the radical by at least $2 \mathrm{~mm}$. Germination energy was recorded after 4 days and germination after 8 days (ISTA, 2008).

After 8 days, 4 replicates $\times 10$ average seedlings were taken from each treatment and used to determine the intensity of lipid peroxidation and free proline content. Intensity of lipid peroxidation was carried out using the method of Placer (1966), free proline concentration was determined by the method of Bates (1973). According to the method of Placer (1966), extraction of malondialdehyde (MDA) from soybean seedling was done by using solution of thiobarbituric acid (TBA), trichloroacetic acid $(\mathrm{CCl} 3 \mathrm{COOH})$ and perchloric acid ( $\mathrm{HClO} 4)$ and concentration was determined spectro photometrically at $532 \mathrm{~nm}$. Soybean seedling $(0.5 \mathrm{~g})$ were homogenized in mortar with $4.5 \mathrm{ml}$ extraction solution and incubated in water bath at $90{ }^{\circ} \mathrm{C}$ for 20 minutes. After incubation, solutions were cooled to stop the reaction and centrifuged for 10 $\mathrm{min}$ at $5500 \mathrm{r} / \mathrm{min}$. MDA concentration i.e. intensity of lipid peroxidation was expressed as nmol of MDA g-1 of fresh weight. Extraction and determination of proline was done according to Bates (1973). Seedlings (1 g) were extracted with $3 \%$ sulphosalicylic acid. Extracts $(2 \mathrm{ml})$ were held for $1 \mathrm{~h}$ in boiling water by adding $2 \mathrm{ml}$ ninhydrin and $2 \mathrm{ml}$ glacial acetic acid, after which cold toluene $(4 \mathrm{ml})$ was added. Proline content was measured by a spectrophotometer at $520 \mathrm{~nm}$ and calculated as molg-1 DW against standard proline.

Data analysis was performed using the statistical software 'Statistica' (StatSoft, Inc., Tulsa, Oklahoma, $\mathrm{SAD}$ ). The obtained data were processed using threefactor analysis of variance. The standard error of the arithmetic mean was used to calculate the significance of the difference using the Tuckey's test.The results presented in the graphs were obtained on the basis of oneway analysis of variance. The interval bars in the figures represent the difference between the standard error of the arithmetic mean.

\section{Results and discussion}

Studies have shown that increasing the intensity of drought from $-0.30 \mathrm{MPa}$ to $-0.80 \mathrm{MPa}$ reduced seed germination and increases the intensity of lipid peroxidation and free proline content. Priming seeds in solutions of $\mathrm{KNO}$, AsA and $\mathrm{KCl}$ reduced the negative impact of drought stress.

All analyzed traits differed significantly at different levels of drought, selected solution, while no difference was found between varieties. A significant difference was also found in the interaction drought stress and solutions, as well as varieties and solution. No interaction was found between cultivar and drought, ie in the case of triple cultivar interaction, drought and solution (Table 1).

\section{Germination energy and germination}

A major limitation in agricultural production worldwide is the drought stress during germination, leading to a decrease or even complete absence of germination (Kaya et al., 2006). Depending on the degree of water deficit, even seed death may occur (Silva et al., 2010). One of the conditions for high yield in conditions of deficit water is to provide fast germination seed and sprouting, and thus help the plants to get out of that phase as soon as possible and develop a root system that will go into deeper layers of soil which have enough water (Gupta et al., 2008). The results of the study showed that drought stress on the germination of soybean seeds was more pronounced at lower water potential of the solution. The results are in line with research conducted on seeds: lentils (Muscolo 
et al., 2014), oats (Mut et al., 2010), sunflower (Ahmad et al., 2009), maize (Mei and Song, 2008) in which it was found that lack of water significantly reduces seed germination. With the increase of drought stress, especially at the lowest value of the water potential of the solution $(-0.80 \mathrm{MPa})$, the time necessary for germination of soybean seeds has been extended (Figure 1,2).

Table 1.

Analysis of the variance of the influence of priming soybean seeds in $\mathrm{KNO}_{3}$, AsA and $\mathrm{KCl}$ solutions on and seedlings in drought conditions.

\begin{tabular}{|c|c|c|c|c|}
\hline \multirow[t]{2}{*}{$\begin{array}{l}\text { Source of } \\
\text { variation }\end{array}$} & 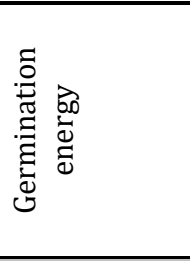 & 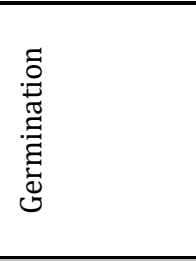 & 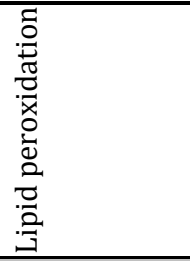 & 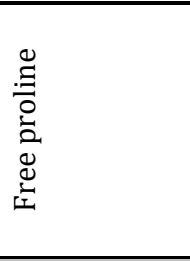 \\
\hline & \multicolumn{2}{|c|}{ Soybean seed } & \multicolumn{2}{|c|}{ Soybean seedling } \\
\hline Variety (A) & 0.47 & 0.92 & 1.45 & 2.78 \\
\hline Drougth (B) & $11.78^{* *}$ & $13.32^{* *}$ & $6.21^{* *}$ & $5.71^{* *}$ \\
\hline Treatment (C) & $5.12^{* *}$ & $5.19^{* *}$ & $4.62^{*}$ & $6.12^{* *}$ \\
\hline$A \times B$ & 0.36 & 1.18 & 2.07 & 2.21 \\
\hline $\mathrm{A} \times \mathrm{C}$ & $7.71^{* *}$ & $8.14^{* *}$ & $5.19^{* *}$ & $5.49^{* *}$ \\
\hline $\mathrm{B} \times \mathrm{C}$ & $8,18^{* *}$ & $9.17^{* *}$ & $5.92^{* *}$ & $6.41^{* *}$ \\
\hline $\mathrm{A} \times \mathrm{B} \times \mathrm{C}$ & 0.29 & 0.34 & 3.29 & 2.19 \\
\hline
\end{tabular}

The significance of the $\mathrm{F}$ test at the level of $5 \%{ }^{*}$ and at the level of $1 \%{ }^{* *}$

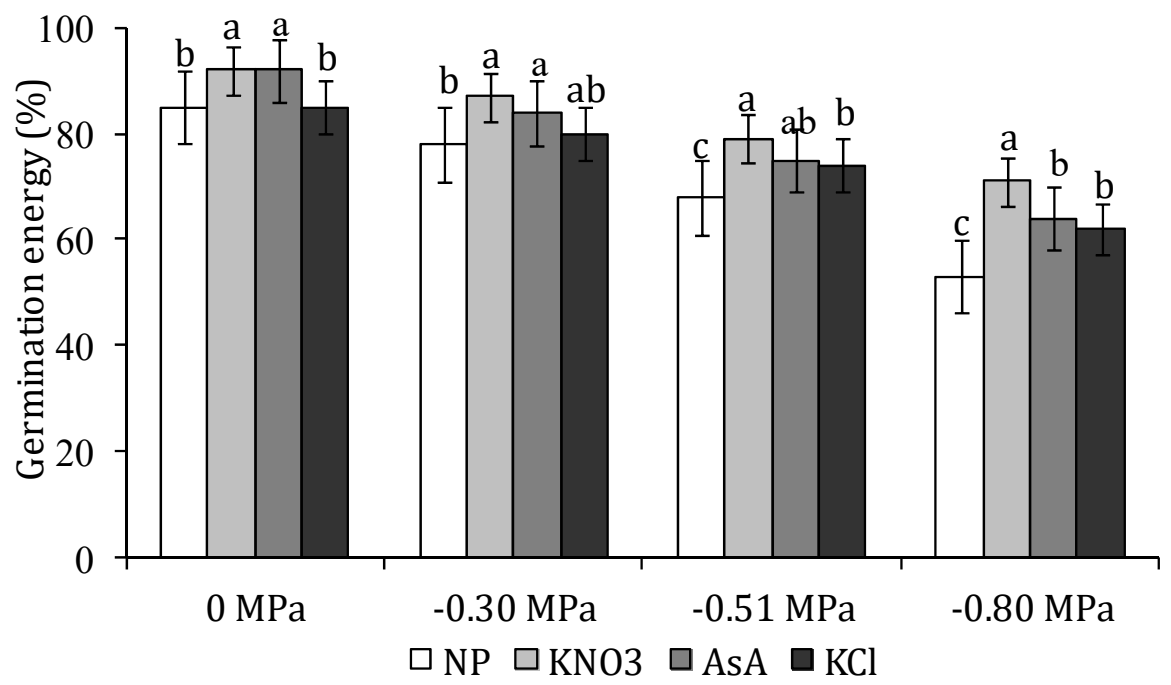

Figure 1. Effect of seed priming in $\mathrm{KNO}$, AsA and $\mathrm{KCl}$ solutions on germination energy in drought stress $(\mathrm{p}<0.05)$ The different letters above the bars indicate a significant difference of $5 \%$. The vertical lines at the top of the columns represent the standard errors according to the treatments shown on the abscissa. 


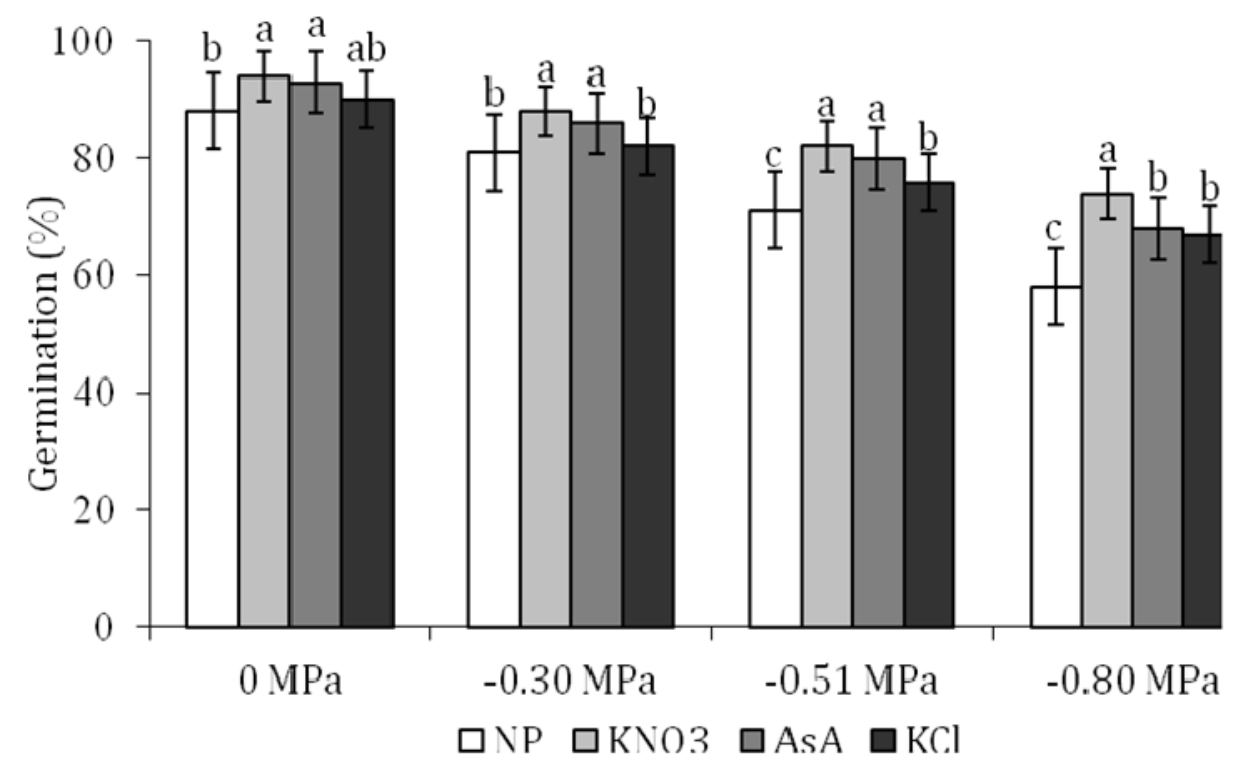

Figure 2. Effect of seed priming in $\mathrm{KNO3}$, AsA and $\mathrm{KCl}$ solutions on germination in drought stress $(\mathrm{p}<0.05)$ The different letters above the bars indicate a significant difference of $5 \%$. The vertical lines at the top of the columns represent the standard errors according to the treatments shown on the abscissa.

Gholami et al. (2010) found that drought stress reduced the activity of hydrolytic enzymes, which are responsible for the decomposition of reserve substances in cotyledons and the provision of energy that is necessary in the initial stages of seed plant development, resulting in inhibition of seed germination. Priming seeds of soybeans in KNO3, AsA and $\mathrm{KCl}$ solutions improved germination energy and seed germination. At the water potential of the solution of $-0.30 \mathrm{MPa}$, the germination energy and germination of primed seeds increased, on average $6.77 \%$ and $5.08 \%$, respectively, while at the water potential of the solution $-0.80 \mathrm{MPa}$, the increase was $19.28 \%$ or $16.75 \%$, respectively. The positive effect of this method due to water deficit can be explained by the fact that priming stimulate germination, accelerates the formation and growth of a root system that will absorb water from deeper layers of soil, resulting in a reduction in the negative impact of deficit water (Zhang et al., 2015). The same authors point out that priming significantly increases the stability of the cell membrane, ie partly eliminates the negative impact of water deficiency on cell membrane degradation. The KNO3 solution had the greatest effect on the seed germination energy. If seed germination is analyzed, it can be seen that KNO3 and AsA have a similar effect. Potassium is a cofactor in the action of some enzymes that play a role in cell division, nucleic acid metabolism and protein synthesis (Cakmak and Horst, 1991). The positive effect of $\mathrm{KNO} 3$ is also attributed to elevated nitrate levels (Benech-Arnold et al., 2000). Nitrates stimulate seed germination because they act as a signaling molecule (Alboresi et al., 2005). A good result was also achieved with the use of AsA. Exogenous application of AsA solution can affect various processes in plants. including seed germination. Ascorbic acid contributes to the regulation of ethylene biosynthesis (Dong et al., 2016), gibberellin (Shu et al., 2013), abscisic acid, and cytokinin (Huang et al., 2017). Giberelins and cytokinins have a predominantly stimulating effect on the germination process, while abscisic acid has an inhibitory effect.

\section{Lipid peroxidation}

As the intensity of drought stress, the intensity of lipid peroxidation increases, and the result is lower germination (Figure 3). Cai et al. (2011) point out that the decrease in seed germination is due to damage to the cell membrane and uncontrolled accumulation of ROS. An increased amount of ROS has the potential to oxidize cellular proteins, lipids, and DNA resulting in a change in structure and function, cell damage and death (Valko et al., 2004). Increased intensity of lipid peroxidation in conditions of drought stress was found in seed rapeseed (Rezayian et al., 2018), Xanthoceras sorbifolium (Cai et al., 2011), Cercidiphyllum japonicum (Mai et al., 2009) and Picea asperata (Yang et al., 2010). Use of priming, intensity of lipid peroxidation is reduced, and the effect is greater at lower water potential of the solution, ie at higher drought intensity. At higher intensity of drought, the effect of priming is greater. Thus, at the water potential of $-0.30 \mathrm{MPa}$, the intensity of lipid peroxidation decreased, on average, by $16.85 \%$, while at the water potential of $-0.80 \mathrm{MPa}$, the decrease was $22.4 \%$. Similar results were received on the seeds of sorghum (Zhang et al., 2015). Chiu et al., (2006) point out that the decrease in lipid peroxidation due to seed priming is a consequence of increased antioxidant activity, and the result of all this is improved seed germination. Bailly et al., (2000) point out that the decrease in the intensity of lipid peroxidation is a consequence of increased enzyme activity. Observing the influence of solutions in these studies, it can be seen that with increasing drought intensity, there is a greater difference in the efficiency of the applied solutions. At higher drought intensities, the effect of KNO3 solution is most effective, while AsA and $\mathrm{KCl}$ solutions have a similar effect. The positive effect of KNO3 on the reduction of the negative effect of drought was determined not only on the example of soybeans (Langeroodi and Noora, 2017) but also on rapeseed (Mohammadi and Amiri, 2010) and Chinese cabbage (Yan, 2015). Potassium from KNO3 plays a key role in reducing the negative impact of 
drought, as it maintains cell turgor due to deficit water land helps maintain the balance of the osmotic potential of the cell and its environment (Umar and Moinuddin 2002). Also, enough provision of plants with this element encourages the growth of the root system, which results in increased water intake from the substrate (Mujtaba et al., 2007).

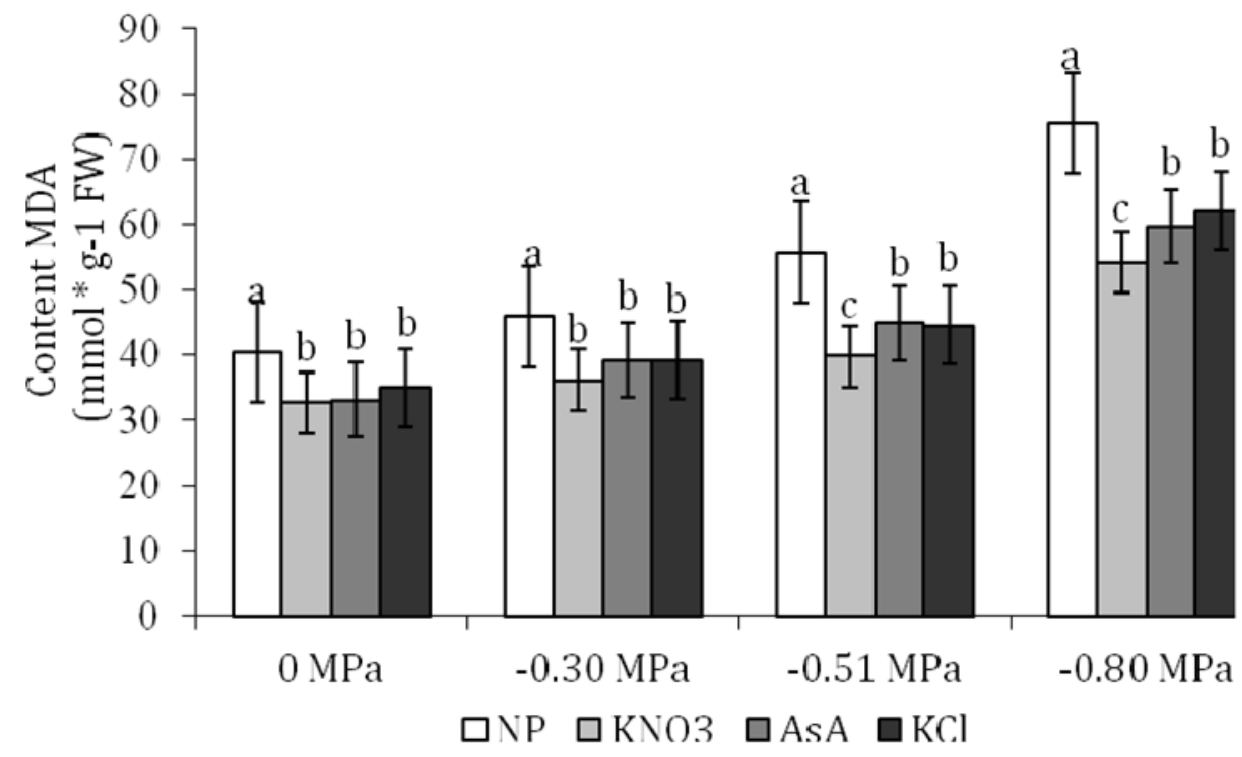

Figure 3. Effect of seed priming in $\mathrm{KNO}$, AsA and $\mathrm{KCl}$ solutions on content MDA in drought stress $(\mathrm{p}<0.05)$ The different letters above the bars indicate a significant difference of $5 \%$. The vertical lines at the top of the columns represent the standard errors according to the treatments shown on the abscissa.

\section{Free proline}

In addition to increasing the intensity of lipid peroxidation, the content of free proline also increases
(Figure 4). The influence of drought stress on its content in soybean seedlings was more pronounced at lower concentrations of water potential.

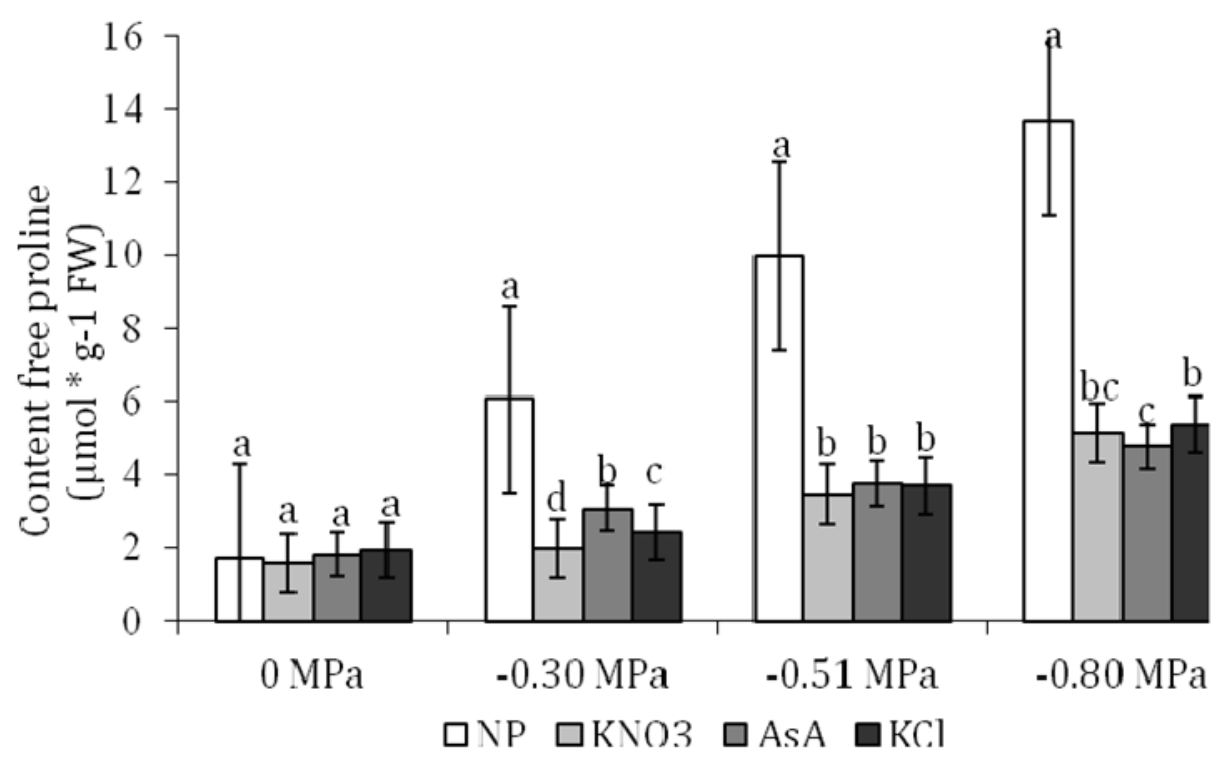

Figure 4. Effect of seed priming in $\mathrm{KNO}$, AsA and $\mathrm{KCl}$ solutions on content free proline in drought stress $(\mathrm{p}<0.05)$ The different letters above the bars indicate a significant difference of $5 \%$. The vertical lines at the top of the columns represent the standard errors according to the treatments shown on the abscissa.

Ashraf and Foolad (2007) point out that one of the mechanisms of protection against osmotic stress, in our research it is drought stress, accumulation of compatible osmolytes (free proline, soluble sugars, glycine betaine and organic acids) in the cytoplasm to keep the cell water potential lower than water potential of the external environment. When exposed to drought, plants accumulate large amounts of free proline, so in some cases its concentration is several times higher than the total concentration of all other amino acids. Increased content of free proline in conditions of drought stress during germination was found in lentils (Muscoli et al., 2013) and millet (Sneha et al., 2014). Priming seeds in solutions of KNO3, AsA 
and $\mathrm{KCl}$, the content of free proline in soybean seedlings was significantly reduced in conditions of lower water potential. Regardless of the water potential, the content of free proline was reduced by more than two times. In addition to the beneficial effect, free proline can also have a negative effect, if it accumulates in a higher concentration. The increased content of free proline results in a disturbance in the relationships between inorganic ions, and the consequence is a decrease in seed germination (Heuer, 2003).

\section{Conclusions}

Quality of soybean seed is reduced in drought stress. As the water potential decreases, germination energy and seed germination decrease significantly, while the intensity of lipid peroxidation and the content of free proline increased. Priming of soybean seed with potassium nitrate, ascorbic acid and potassium chloride solutions resulted in the higher seed quality regardless of the soybean variety or water potential. Application of pre-sowing treatment might be used for improving germination in the case of crop cultivation under drought stress conditions. Improved germination would also affect crop canopy and ensure crop stability, ultimately resulting in higher and stable yields.

\section{Acknowledgement}

This research was supported by the Ministry of Education, Science and Technological Development of the Republic of Serbia, grant number: 451-03-68/2020$14 / 200032$. Also, this article is part the project 114451-2739/2016 Sustainable production of plant proteins: soybean, microorganisms, response to climate change" financially supported by the Provincial Secretariat for Science and Technological Development. We express our sincerest gratitude to them for support.

\section{References}

Ahmad, S., Ahmad, R., Ashraf, M.Y., Ashraf, M., Waraich, E.A. (2009). Sunflower (Helianthus annuus L.) response to drought stress at germination and seedling growth stages. Pakistan Journal of Botany, 41, 647-654.

Alboresi, A., Gestin, C., Leydecker, M.T., Bedu, M., Meyer, C., Truong H.N. (2005). Nitrate, a signal relieving seed dormancy in Arabidopsis. Plant, Cell \& Environment, 28 (4), 500-512.

Alexieva, V., Sergiev, I., Mapelli, S., Karanov, E. (2001). The effect of drought and ultraviolet radiation on growth and stress markers in pea and wheat. Plant, Cell \& Environment, 24, 1337-1344.

Ashraf M., Foolad M. R. (2007): Improving plant abiotic-stress resistance by exogenous application of osmoprotectants glycine betaine and proline. Environmental and Experimental Botany, 59: 206-216.

Bailly, C., Benamar, A., Corbineau, F., Côme, D. (2000). Antioxidant systems in sunflower (Helianthus annuus L.) seeds as affected by priming. Seed Science Research, 10, 35-42.

Bates, L.S., Waklren, R.P., Teare, I.D. (1973). Rapid determination of free proline water stress studies. Plant and Soil, 39, 205-207.

Benech-Arnold, R.L., Sanchez, R.A., Forcella, F., Kruka, B.C. Ghersa, C.M. (2000). Environmental control of dormancy in weed seed banks in soil. Field Crops Research, 67, 105122.

Benderitter, M., Maupoli, V., Vergely, C., Dalloz, F., Briot, F., Rochette, L. (1998). Studies by electron paramagnetic resonance of the importance of iron in the hydroxyl scavenging properties of ascorbic acid in plasma: Effects of iron chelators. Fundamental of Clinical Pharmacology, 12: $510-516$.

Cai, F., Mei, L.J., An, X.L., Gao S., Tang, L., Chen F. (2011). Lipid peroxidation and antioxidant responses during seed germination of Jatropha curcas. International Journal of Agricultural and Biological Engineering, 13 (1), 25-30.

Cakmak, I., Horst, W.J. (1991). Effect of aluminium on lipid peroxidation, superoxide dismutase, catalase, and peroxidase activities in root tips of soybean (Glycine max). Physiology Plantarum, 83, 463-468.

Chiu, K.Y., Chuang, S.J., Sung, J.M. (2006). Both anti-oxidation and lipid-carbohydrate conversion enhancements are involved in priming-improved emergence of Echinacea purpurea seeds that differ in size. Scientia Horticulturae, 108: 220-226.

Dong, Z., Yu, Y., Li, S., Wang, J., Tang, S., Huang, R. (2016). Abscisic acid antagonizes ethylene production through the ABI4-mediated transcriptional repression of ACS4 and ACS8 in Arabidopsis. Molecular Plant, 9, 126-135.

Evenari, M. (1984). Seed physiology: its history from antiquity to the beginning or the 20th Century. Botanical Review, 50, 119-142.

Gholami, M., Rahemi, M., Kholdebarin, B. (2010). Effect of drought stress induced by polyethyleneglycol on seed germination of four wild almond species. Australian Journal of Basic and Applied Sciences, 4 (5), 785-791.

Gupta, A., Dadlani, M., Arun Kumar, M.B., Roy, M., Naseem, M., Choudhary, V.K., Maiti, R.K. (2008). Seed Priming: the aftermath. International Journal of Agriculture. Environment and Biotechnology, 1, 199-209.

Harris, D., Pathan, A.K., Gothkar, P., Joshi, A., Chivasa, W., Nyamudeza, P. (2001). On farm seed priming: using participatory method to revive and refine a key technology. Agricultural Systems, 69, 151-164.

Heuer B. (2003): Influence of exogenous application of proline and glycinebetaine on growth of salt-stressed tomato plants. Plant Science, 165, 693-699.

Huang, X., Zhang, X., Gong, Z., Yang, S., Shi, Y. (2017). ABI4 represses the expression of type-A ARRs to inhibit seed germination in Arabidopsis. Plant Journal, 89, 354-365.

ISTA (International seed testing association) (2008). International Rules for Seed Testing. ISTA, Zurich. https://www.seedtest.org/en/ home.html

Kaya, M. D., Okcu, G., Atak, M., Cikili, Y., Kolsarici, O. (2006). Seed treatments to overcome salt and drought stress during germination in sunflower (Helianthus annuus L.). European Journal of Agronomy, 24, 291-295.

Khajeh-Hosseini, M., Powell, A.A., Bimgham, I.J. (2003). The interaction between salinity stress and seed vigor during germination of soybean seeds. Seed Science and Technology, 31, 715-725.

Langeroodi, A.R.S., Noora R. (2017). Seed priming improves the germination and field performance of soybean under drought stress. Journal of Animal and Plant Sciences, 27 (5), 1611-1620.

Mai, M.M., Shi, D.X., Wang, M.L., Li, W. (2009): Seed germination and seedling growth of Cercidiphyllum japonicum. Sci. Silv. Sin., 10, 94-99.

Mei, Y.Q., Song S.Q. (2008). Early morphological and physiological events occurring during germination of maize seeds. Agricultural Sciences in China, 7, 950-957.

Miladinov, Z., Balešević-Tubić, S., Đorđević, V., Đukić, V., Ilić A. Čobanović, L. (2015). Optimal time of soybean seed priming and primer effect under salt stress conditions. Journal of Agricultural Sciences, 60, 109-117.

Mohammadi, G. R., Amiri, F. (2010). The effect of priming on seed performance of canola (Brassica napus L.) under drought stress. American-Eurasian Journal of Agricultural \& Environmental Sciences, 9(2), 202-207.

Mujtaba, S.M., Ali, M., Ashraf, M.Y., Khanzada, B., Farhan, S.M., Shirazi, M.U., Khan M.A., Shereen. A., Mumtaz, S. (2007). Physiological responses of wheat (Triticum aestivum L.) genotypes under water stress conditions at seedling stage. Pakistan Journal of Botany, 39 (7), 2575-2579. 
Murillo-Amador, B., Lopez-Aguilar, R., Kaya, C., LarrinagaMayoral, J., Flores-Hernandez, A. (2002). Comparative effects of $\mathrm{NaCl}$ and polyethylene glycol on germination, emergenceand seedling growth of cowpea. Journal of Agronomy and Crop Science, 188, 235-247.

Muscolo, A., Sidaria, M., Anastasib, U., Santonocetoa, C., Maggioc, A. (2014). Effect of PEG-induced drought stress on seed germination of four lentil genotypes. Journal of Plant Interactions, 9 (1), 354-363.

Mut, Z., Akay, H., Aydin, N. (2010). Effects of seed size and drought stress on germination and seedling growth of some oat genotypes (Avena sativa L.). African Journal of Aricultural Research, 5, 1101-1107.

Ozdemir, E., Sade, B., Soylu, S. (2012). Effects of seed priming on growth parameters and relative water content of bread wheat cultivars at drought and normal conditions. Journal of Selcuk University Agriculture and Food Sciences, 26, 25-30.

Placer Z. A., Cushman L. L., Johnson B. C. (1966): Estimation of product of lipid peroxidation (malonyl dialdehyde) in biochemical systems. Analytical Biochemistry, 16: 359364.

Rezayian, M., Niknam, V., Ebrahimzadeh, H. (2018). Effects of drought stress on the seedling growth, development, and metabolic activity in different cultivars of canola. Soil Science and Plant Nutrition, 64 (3), 360-369.

Silva, E. C., Silva, M. F. A., Nogueira, R. J. M. C., Albuquerque, M. B. (2010). Growth evaluation and water relations of Erythrina velutina seedlings in response to drought stress. Brazilian Journal of Plant Physiology, 22, 225-233.

Sivasubramaniam, K., Geetha, R., Sujatha ,K., Raja, K., Sripunitha, A., Selvarani, R. (2011). Seed priming: triumphs and tribulations. The Madras Agricultural Journal, 98, 197-209.

Sneha, S., Rishi, A., Chandra, S. (2014). Effect of short term salt stress on chlorophyll content, protein and activities of catalase and ascorbate peroxidase enzymes in Pearl Millet. American Journal of Plant Patology, 9, 32-37.

Shu, K., Zhang, H.W., Wang, S.F., Chen, M.L., Wu, Y.R., Tang, S., Liu, C., Feng, Y., Cao, X., Xie, Q. (2013). ABI4 regulates primary seed dormancy by regulating the biogenesis of abscisic acid and gibberellins in Arabidopsis. Plos Genetics, 9.

Umar, S. (2002). Moinuddin genotypic differences in yield and quality of groundnut as affected by potassium nutrition under erratic rainfall conditions. Journal of Plant Nutrition, 25: 1549-1562.

Valko, M., Izakovic, M., Mazur, M., Rhodes, C. J., Telser J. (2004). Role of oxygen radicals in DNA damage and cancer incidence. Molecular and Cellular Biochemistry, 266(1-2), 3756.

Yan, M. (2015), Seed priming stimulate germination and early seedling growth of Chinese cabbage under drought stress. South African Journal of Botany, 99, 88-92.

Yang, Y., Liu, Q., Wang, G. X., Wang, X. D., Guo, J. Y. (2010). Germination, osmotic adjustment, and antioxidant enzyme activities of gibberellinpretreated Picea asperata seeds under water stress. New Forest, 39 (2), 231-243.

Zhang, F., Yu, J., Johnston, C.R., Wang, Y., Zhu, K., Lu F. (2015). Seed priming with polyethylene glycol induces physiological changes in sorghum (Sorghum bicolor L. Moench) seedlings under suboptimal soil moisture $\begin{array}{lllll}\text { environments. PLOS ONE } 10 & \text { (10): } & \text { e0140620 }\end{array}$ 